\title{
Salinity Affects Quality Parameters of 'SeaDwarf' Seashore Paspalum
}

\author{
William L. Berndt \\ Division of Professional and Technical Studies, Edison College, 8099 \\ College Parkway S.W., P.O. Box 60210, Building C-101, Fort Myers, FL \\ 33906-6210
}

Additional index words. electrical conductivity, irrigation, morphology, osmotic stress, salinity, 'SeaDwarf', seashore paspalum, Paspalum vaginatum, visual quality

\begin{abstract}
Irrigating salt-tolerant grasses with nonpotable water, like salt water, conserves fresh water resources. Advertising suggests that 'SeaDwarf' seashore paspalum (Paspalum vaginatum $O$. Swartz) is salt-tolerant and that it resists the effects of salinity on growth typically observed when irrigating other turf types with salty water. As a result, it is now being used on golf courses and home lawns in an effort to help conserve fresh water. Commensurate with the use of nonpotable irrigation, however, would be an expectation of high turf quality. This study was done to determine if the quality of 'SeaDwarf' seashore paspalum was affected by irrigating it with nonpotable water having high levels of salinity. Seven irrigation water sources created by blending tap water and ocean water and ranging in salinity from 0.52 to $49.40 \mathrm{dS} \cdot \mathrm{m}^{-1}$ were used to flood-irrigate containerized 'SeaDwarf' seashore paspalum once daily for 50 consecutive days. Turf quality gradually decreased as salinity increased but improved with time except at the highest level of salinity. Effect of water source on turf quality was attributed to salinity-induced changes in quality parameters, including leaf texture, color, stolon growth, and shoot yield. The observed effect of salinity on quality parameters likely resulted from osmotic stress associated with high levels of salinity. The salt tolerance of 'SeaDwarf' seashore paspalum in this study was moderately good, but irrigating it with water having lower levels of salinity resulted in better quality turf.
\end{abstract}

'SeaDwarf' seashore paspalum is now being used as a golf course turf in many different warm season locations, including the United States, Mexico, the Caribbean, and Spain (Duncan and Carrow, 2005). 'SeaDwarf' seashore paspalum is a halophytic, dwarf cultivar originating at Alden Pines golf course in Bokeelia, Fla., during the 1980s (Duncan, 2001; Saltscape Solutions, 2006). It is marketed by Environmental Turf of Fort Pierce, Fla., and sold through licensed growers (Environmental Turf, 2006; Zinn, 2004a, 2004b). It is a fine-textured turfgrass used primarily for putting greens but is now being used for greens, tees, fairways, approaches, and roughs on six golf courses in Florida (Lou Conzelmann, WCI, pers. comm., Oct. 2006) as well as for residential lawns and sports fields at a variety of locations (Zinn, 2004a, 2004b).

The popularity of 'SeaDwarf' seashore paspalum has resulted, in part, from research citing seashore paspalum as being the most salt-tolerant turfgrass (Duncan and Carrow, 2000) along with an intensive, private-sector marketing campaign (Environmental Turf, 2006; Zinn, 2004a, 2004b). 'SeaDwarf' seashore paspalum is advertised to be tolerant to levels of salinity of up to $34.4 \mathrm{dS} \cdot \mathrm{m}^{-1}$ or higher (Environmental Turf, 2006). It has been said that sea spray will not affect it and

Received for publication 2 Nov. 2006. Accepted for publication 20 Nov. 2006

E-mail lberndt@edison.edu. that sea water can be used for irrigating it (Environmental Turf, 2006). Irrigating 'SeaDwarf' seashore paspalum using nonpotable water such as brackish water would help to conserve potable water resources. Commensurate with the use of nonpotable irrigation, however, would be an expectation of high turf quality.

Little if any information specific to 'SeaDwarf' seashore paspalum and salinityrelated quality exists in the scientific literature. No published record of data could be found for 'SeaDwarf' seashore paspalum and apparently there is no published universityoriented comparative research with currently available cultivars (Duncan, 2001). Public information on the diversity of salinity tolerance of cultivars of seashore paspalum in general is also limited (Lee et al., 2005). With this in mind, a container-oriented investigation involving established 'SeaDwarf' seashore paspalum was conducted at Edison College in Fort Myers, Fla., in 2002. The objectives of this research were 1) to determine if the quality of 'SeaDwarf' seashore paspalum was affected as a result of irrigating it with water having high levels of salinity, and 2) to provide researchers and end users with basic information regarding the effects that high levels of salinity may have on the quality of 'SeaDwarf' seashore paspalum.

\section{Materials and Methods}

Forty-two plugs of 'SeaDwarf' seashore paspalum were obtained from Alden Pines
Golf Course in Bokeelia, Fla., using a 10.8-cm diameter cup cutter (Par Aide, Lino Lakes, Minn.). Experimental units were created by first washing plugs with water to remove soil, then transplanting clean plugs into No. 6 clay pots containing equal volumes of sand (No. 200 construction grade sand; Rymatt Golf, Naples, Fla.) having $>70 \%$ of particles in the $1.00-$ to $0.25-\mathrm{mm}$ fraction. Experimental units were then placed in full sun for $45 \mathrm{~d}$ to allow turf to spread and completely cover the surface of the sand inside each pot. During the 45 -d period, turf was maintained in a manner similar to the care of turf in field conditions. It was clipped daily at a height of cut of $6 \mathrm{~cm}$, fertilized weekly by drenching with soluble 20-16.68.8 at a rate of $12.2 \mathrm{~kg} \cdot \mathrm{ha}^{-1} \mathrm{~N}$ and irrigated as needed with tap water having an electrical conductivity $\left(E C_{i w}\right)$ of $0.52 \mathrm{dS} \cdot \mathrm{m}^{-1}$.

Experimental units were then randomly arranged into seven groups of six pots each. Each group was randomly assigned to be irrigated with one of seven experimental irrigation water sources, each having a differing $\mathrm{EC}\left(E C_{i w}\right)$, sodium adsorption ratio, and so on. Water sources (treatments) consisted of sea water taken from the Gulf of Mexico at Fort Myers Beach, Fla. $\left(26.4500^{\circ} \mathrm{N}\right.$, $\left.81.9508^{\circ} \mathrm{W}\right)$, potable tap water from Lee County, Fla., utilities, and five blends of these two waters created by mixing one part sea water with from one to five parts tap water (Table 1). Potable tap water was considered a control. Values presented in Table 1 are the results of irrigation water suitability analyses conducted by A \& L Southern Agricultural Laboratories (Fort Lauderdale, Fla.).

Each experimental unit was brought to its field capacity each day by flood irrigating with $250 \mathrm{~mL}$ of water, according to treatment, for 50 consecutive days beginning 11 Feb. 2002. This was done to ensure water was not limiting for turf growth. Excess water drained freely. Mowing and fertilization were discontinued. Quality ratings were taken four times during the 50-d treatment period. Rating dates were $14 \mathrm{Feb}$., which was $3 \mathrm{~d}$ after the onset of the study, and then again on 21 Feb., 12 Mar., and 21 Mar. Perfect quality turf was given a score of 10.0 , whereas a score of 1.0 was given to dead turf. For this study, quality was defined as a composite of visible turfgrass traits and factors and was a function of the turf's overall appearance (Beard, 1973; Turgeon, 2002). Quality ratings considered elements of both visual quality and functional quality (Beard, 1973), including leaf texture, color, growth habit, and shoot growth.

A leaf texture rating $(10=$ coarse $; 1=$ fine $)$ was taken on day 50 of the study. The total number $(\mathrm{n})$ and corresponding length $(\mathrm{mm})$ of each visible stolon was also determined. Shoot tissue from each pot was then harvested using shears. Moisture content $\left(\mathrm{g} \cdot \mathrm{kg}^{-1}\right)$ was determined for a portion of fresh shoot tissue by oven-drying for $24 \mathrm{~h}$ at $104^{\circ} \mathrm{C}$ (Undersander et al., 2003). Remaining tissue was oven-dried at $60{ }^{\circ} \mathrm{C}$ for $48 \mathrm{~h}$ and then weighed $(\mathrm{g})$. Chlorophyll concentrations 
Table 1 . Results of water quality analyses for seven experimental irrigation water sources.

\begin{tabular}{|c|c|c|c|c|c|c|c|}
\hline & \multicolumn{7}{|c|}{ Water source descriptor } \\
\hline & $\operatorname{Tap}^{\mathrm{z}}$ & $5: 1^{y}$ & $4: 1$ & $3: 1$ & $2: 1$ & $1: 1$ & $\mathrm{Sea}^{\mathrm{x}}$ \\
\hline$\overline{E C_{i w} \mathrm{dS} \cdot \mathrm{m}^{-1}}$ & 0.52 & 10.10 & 11.70 & 14.70 & 19.10 & 27.40 & 49.40 \\
\hline $\mathrm{TDS}^{\mathrm{w}} \mathrm{mg} \cdot \mathrm{L}^{-1}$ & 332 & 6464 & 7488 & 9408 & 12,224 & 17,536 & 31,616 \\
\hline Salinity hazard ${ }^{\mathrm{v}}$ & Medium & Very high & Very high & Very high & Very high & Very high & Very high \\
\hline $\mathrm{Na}^{+} \mathrm{mg} \cdot \mathrm{L}^{-1}$ & 53 & 1700 & 2100 & 2500 & 3200 & 4200 & 7000 \\
\hline $\mathrm{Ca}^{2+} \mathrm{mg} \cdot \mathrm{L}^{-1}$ & 35 & 80 & 90 & 100 & 130 & 200 & 330 \\
\hline $\mathrm{Mg}^{2+} \mathrm{mg} \cdot \mathrm{L}^{-1}$ & 8 & 260 & 260 & 340 & 400 & 640 & 1180 \\
\hline $\mathrm{SAR}^{\mathrm{u}}$ & 2.08 & 20.43 & 24.99 & 26.36 & 30.86 & 32.12 & 39.76 \\
\hline Sodium hazard ${ }^{\mathrm{v}}$ & Low & Very high & Very high & Very high & Very high & Very high & Very high \\
\hline Water class ${ }^{\mathrm{v}}$ & $\mathrm{C} 2-\mathrm{S} 1$ & $\mathrm{C} 4-\mathrm{S} 4$ & C4-S4 & C4-S4 & $\mathrm{C} 4-\mathrm{S} 4$ & C4-S4 & $\mathrm{C} 4-\mathrm{S} 4$ \\
\hline $\mathrm{pH}$ & 7.3 & 7.7 & 7.8 & 7.8 & 7.9 & 7.9 & 7.7 \\
\hline $\mathrm{P} \mathrm{mg} \cdot \mathrm{L}^{-1}$ & 0.08 & 0.03 & 0.06 & 0.07 & 0.06 & 0.05 & 0.04 \\
\hline $\mathrm{K}^{+} \mathrm{mg} \cdot \mathrm{L}^{-1}$ & 1 & 60 & 60 & 80 & 100 & 160 & 340 \\
\hline $\mathrm{Fe}^{2+} \mathrm{mg} \cdot \mathrm{L}^{-1}$ & 1.05 & 0.01 & 0.01 & 0.02 & 0.10 & 0.15 & 0.09 \\
\hline $\mathrm{B}^{3+} \mathrm{mg} \cdot \mathrm{L}^{-1}$ & 0.06 & 0.30 & 0.40 & 0.56 & 1.00 & 1.62 & 4.96 \\
\hline $\mathrm{NO}_{3}^{-} \mathrm{mg} \cdot \mathrm{L}^{-1}$ & 7 & 6 & 6 & 6 & 6 & 6 & 7 \\
\hline $\mathrm{Cl}^{-} \mathrm{mg} \cdot \mathrm{L}^{-1}$ & 145 & 2780 & 3110 & 4050 & 5920 & 7890 & 18,500 \\
\hline $\mathrm{SO}_{4}^{2-} \mathrm{mg} \cdot \mathrm{L}^{-1}$ & 42 & 180 & 390 & 450 & 780 & 1680 & 2220 \\
\hline $\mathrm{HCO}_{3}{ }^{-} \mathrm{mg} \cdot \mathrm{L}^{-1}$ & 64 & 90 & 98 & 112 & 119 & 123 & 156 \\
\hline
\end{tabular}

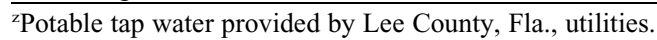

${ }^{\mathrm{y}}$ Five parts tap water blended with one part sea water.

Sea water taken from the Gulf of Mexico at Fort Myers Beach, Fla.

wTotal dissolved solids.

vichards, 1954.

"Sodium adsorption ratio.

(chlorophyll A and $\mathrm{B} \mathrm{mg} \cdot \mathrm{g}^{-1}$ tissue) were determined for samples of oven-dried shoot tissue (Johnson, 1974). This procedure specifically called for the drying of clippings at $60{ }^{\circ} \mathrm{C}$. The EC of a $1: 1$ extract or $E C_{I}$ (Richards, 1954) of the soil was determined using a Hanna DIST WP4 conductivity cell (Hanna Instruments, Woonsocket, R.I.). For this, duplicate 50-g samples of soil were suspended in $50 \mathrm{~mL}$ distilled, deionized water and allowed to equilibrate for $24 \mathrm{~h}$. Values of $E C_{1}$ were reported in $\mathrm{dS} \cdot \mathrm{m}^{-1}$.

This experiment was conducted as a completely randomized design with six replications of each treatment. All data were subject to analysis of variance (ANOVA) or regression analysis. Quality rating scores compiled for each rating date were analyzed by ANOVA for a split plot in time (Steel and Torrie, 1980) to determine the effect of time on the level of turf quality as affected by water source. For this, water sources (W) were considered whole plots with $6 \mathrm{df}$, and $35 \mathrm{df}$ for the error term, whereas rating dates (D) were subplots with $3 \mathrm{df}, 18 \mathrm{df}$ for the $\mathrm{W} \times \mathrm{D}$, and $105 \mathrm{df}$ for the subplot error term. Quality rating score means for each rating date were then regressed on the salinity level of each irrigation water source expressed as $\mathrm{EC}$ of the irrigation water $\left(E C_{i w}\right)$. Data from other dependent variables were analyzed as a completely randomized design, with 6 and $35 \mathrm{df}$ for water source and the error term, respectively. Means were separated using least significant differences. Means of select dependent variables were also regressed on $E C_{i w}$ so as to predict yield decreases and so on.

\section{Results and Discussion}

With respect to quality ratings, the interaction between irrigation water source and rating date was highly significant (Table 2). As a result, the turf response to water source

Table 2. Quality rating means $(10=$ perfect and $1=$ dead $)$ and analysis of variance.

\begin{tabular}{|c|c|c|c|c|c|c|}
\hline \multirow[b]{2}{*}{ Water source } & \multicolumn{5}{|c|}{ Turf quality rating dates } & \multirow[b]{2}{*}{$\operatorname{LSD}_{P}=0.01$} \\
\hline & $14 \mathrm{Feb}$. & $21 \mathrm{Feb}$. & 12 Mar. & 21 Mar. & Mean & \\
\hline \multicolumn{7}{|c|}{ Turf quality rating means } \\
\hline Tap water & 6.9 & 7.8 & 8.4 & 9.2 & 8.1 & $0.5^{\mathrm{z}}$ \\
\hline $5: 1$ blend $^{\mathrm{x}}$ & 6.6 & 7.2 & 8.0 & 8.9 & 7.7 & \\
\hline $4: 1$ blend & 7.5 & 7.9 & 8.5 & 8.9 & 8.2 & \\
\hline $3: 1$ blend & 6.7 & 6.8 & 7.6 & 8.7 & 7.5 & \\
\hline 2:1 blend & 6.4 & 6.4 & 7.5 & 8.7 & 7.2 & \\
\hline $1: 1$ blend & 5.9 & 5.3 & 5.8 & 7.5 & 6.1 & \\
\hline Sea water & 5.1 & 3.0 & 2.3 & 2.1 & 3.1 & \\
\hline $\operatorname{LSD}_{P}=0.01$ & $1.1^{\mathrm{y}}$ & 1.1 & 0.8 & 0.4 & 0.8 & \\
\hline \multicolumn{7}{|c|}{ Analysis of variance } \\
\hline Variation & $\mathrm{df}$ & MS & $\mathrm{F}$ & $P=0.05$ & $P=0.01$ & $\operatorname{LSD}_{P}=0.01$ \\
\hline Water (W) & 6 & 75.67 & $78.01 * *$ & 2.38 & 3.38 & 0.77 \\
\hline Error (W) & 35 & 0.97 & & & & \\
\hline Date (D) & 3 & 15.18 & $168.67 * *$ & 2.70 & 4.00 & 0.17 \\
\hline $\mathrm{W} \times \mathrm{D}$ & 18 & 4.39 & $48.78 * *$ & 1.68 & 2.07 & \\
\hline Error (D) & 105 & 0.09 & & & & \\
\hline
\end{tabular}

$*, * *$ Significant at the $5 \%$ level and the $1 \%$ level, respectively.

${ }^{z}$ Value of LSD $P=0.01$ for any 2 means within water sources.

${ }^{y}$ Value of LSD $P=0.01$ for any 2 means within rating date.

${ }^{x}$ Five parts tap water blended with one part sea water.

LSD $=$ least significant difference.

was presented by regression analysis (Fig. 1). Significant differences in turf quality were apparent for the first rating event, which occurred only $3 \mathrm{~d}$ after irrigation treatments were initiated. This meant that the onset of the effect of water source on turf quality happened very quickly. Differences in quality among water sources became more distinct with time, citing increasing variation among water sources and decreasing variation within water sources. Quality scores within water sources improved with time, except for the sea water treatment and to some extent the 1:1 blend, hence the significant interaction. Thus, in this study, it appeared that the length of exposure to an irrigation water source with a given salinity level, as well as the salinity level per se, was important in producing an effect on the quality of 'SeaDwarf'.
The effect of water source on turf quality was attributed to salinity-induced changes in parameters of turf quality, including chlorophyll content, leaf texture, aerial shoot yield, and the number and corresponding length of lateral stems as stolons (Table 3 ). For example, it was evident that the chlorophyll content of shoots and leaves gradually decreased in response to increasing salinity causing turf color to fade slightly. Leaf texture also became much finer. Together, color and texture are highly important determinants of turf quality (Beard, 1973).

The effect salinity had on shoot yield was prominent. From regression analysis of shoot yield means on $E C_{i w}\left(\mathrm{R}^{2}=0.98 ; \hat{\mathrm{Y}}=387.14-\right.$ $\left.13.52 \mathrm{X}+0.1308 \mathrm{X}^{2}\right)$, the predicted value in which shoot yield was reduced by $50 \%$ compared with the control $\left(E C_{i w} 50\right)$ was $17.4 \mathrm{dS} \cdot \mathrm{m}^{-1}$. This result was similar with 

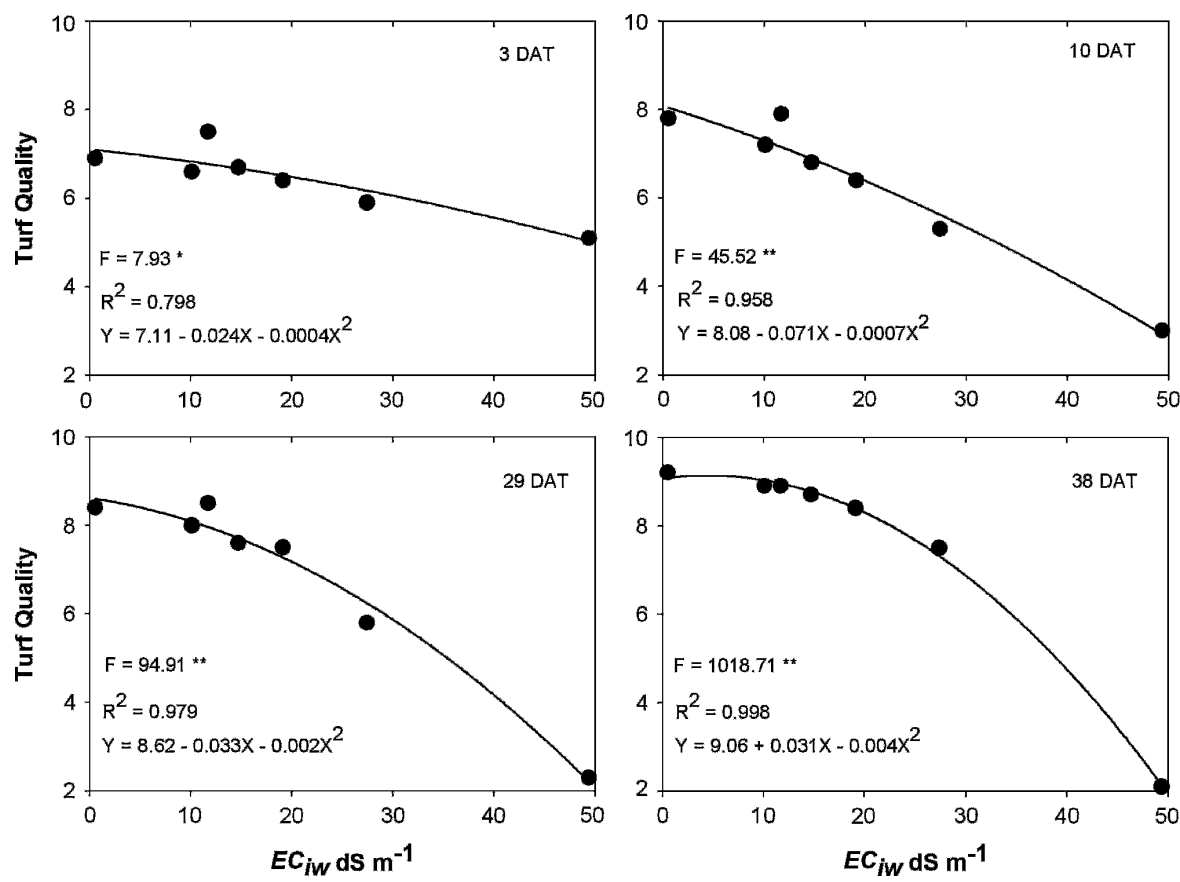

Fig. 1. The influence of seven experimental irrigation water sources on the quality of 'SeaDwarf' seashore paspalum. Quality rating dates were 14 Feb., 21 Feb., 12 Mar., and 21 March. DAT refers to days after irrigation treatments began.

Table 3. Analysis of variance summaries and treatment means for EC of soil $\left(E C_{1}\right)$ and for select quality parameters. $^{\mathrm{z}}$

\begin{tabular}{|c|c|c|c|c|c|c|c|c|}
\hline \multirow[b]{3}{*}{ Source of variation } & \multirow[b]{3}{*}{$\mathrm{df}$} & \multicolumn{7}{|c|}{ Quality Parameters } \\
\hline & & $E C_{I}^{y}$ & Chlorophyll $^{\mathrm{x}}$ & Texture $^{w}$ & Yield $^{v}$ & Number $^{\mathrm{u}}$ & Length $^{\mathrm{u}}$ & Moisture $^{t}$ \\
\hline & & \multicolumn{7}{|c|}{ Mean squares } \\
\hline Water source & 6 & $2.18^{* *}$ & $9.02 * *$ & $13.3^{* *}$ & $74,026 * *$ & $2758 * *$ & $15,602 * *$ & $75 * *$ \\
\hline Error & 35 & 0.03 & 0.08 & 0.03 & 2,151 & 11 & 467 & 12 \\
\hline Water source & & \multicolumn{7}{|c|}{ Treatment means } \\
\hline Tap water & & 0.05 & 3.86 & 6.5 & 383 & 25 & 143 & 779 \\
\hline $5: 1$ blend & & 0.50 & 3.96 & 5.2 & 242 & 6 & 51 & 777 \\
\hline $4: 1$ blend & & 0.78 & 3.79 & 5.2 & 245 & 4 & 53 & 782 \\
\hline $3: 1$ blend & & 0.80 & 3.68 & 4.8 & 246 & 3 & 36 & 777 \\
\hline $2: 1$ blend & & 1.07 & 3.74 & 4.8 & 174 & 0 & 0 & 769 \\
\hline $1: 1$ blend & & 1.23 & 3.50 & 3.8 & 108 & 0 & 0 & 754 \\
\hline Sea water & & 1.96 & 1.10 & 1.7 & 39 & 0 & 0 & 709 \\
\hline $\begin{array}{l}\text { Least significant } \\
\quad \text { difference } P=0.01\end{array}$ & & 0.27 & 0.40 & 0.3 & 73 & 5 & 34 & 53 \\
\hline
\end{tabular}

*,**Significant at the $5 \%$ level and the $1 \%$ level, respectively.

${ }^{z}$ Tabled values are mean squares and treatment means, respectively.

${ }^{\mathrm{y}} \mathrm{EC}$ of a 1:1 extract of soil:distilled water in $\mathrm{dS} \cdot \mathrm{m}^{-1}$.

${ }^{\mathrm{x}}$ Chlorophyll A $+\mathrm{B} \mathrm{mg} \cdot \mathrm{g}^{-1}$ shoot tissue.

${ }^{\mathrm{w}}$ Leaf texture rating in which $10=$ coarse and $1=$ fine.

vield of shoots $\mathrm{g} \cdot \mathrm{m}^{-2}$.

Number of stolons $\cdot$ unit $^{-1}$ and corresponding stolon length ( $\left.\mathrm{mm}\right)$.

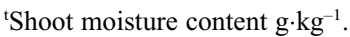

$\mathrm{EC}=$ electrical conductivity.

the $E C_{i w} 50$ value for top growth predicted by inverse regression analysis for 'Adalayd' seashore paspalum grown in solution culture in a glasshouse experiment (Dudeck and Peacock, 1985). The 'Adalayd' exhibited $50 \%$ top growth reduction at $18.4 \mathrm{dS} \cdot \mathrm{m}^{-1}$ and was deemed the most salt sensitive cultivar in that study. The predicted value of $E C_{i w} 25$, where shoot yield of 'SeaDwarf' was reduced by $25 \%$ was $8 \mathrm{dS} \cdot \mathrm{m}^{-1}$, which was identical to the value for $E C_{i w} 25$ shoot yield of 'Adalayd' as published by Lee et al. (2002). The salinity tolerance of 'SeaDwarf' in this study was similar to 'Adalayd' and would be considered moderate (Duncan, 2001).

The effect salinity had on stolon growth was particularly pronounced. Increasing the $E C_{i w}$ from $0.52 \mathrm{dS} \cdot \mathrm{m}^{-1}$ (tap water) to 10.1 $\mathrm{dS} \cdot \mathrm{m}^{-1}(5: 1$ blend $)$ resulted in a $76.0 \%$ reduction in the number of stolons present after $50 \mathrm{~d}$. There was also a corresponding reduction in stolon length of $64.3 \%$. From regression analysis of stolon length means on $E C_{i w}\left(\mathrm{R}^{2}=0.95 ; \hat{\mathrm{Y}}=142.53-7.77 \mathrm{X}\right)$, the $E C_{i w} 50$, or salinity value where stolon length was reduced by $50 \%$, was calculated to be $9.1 \mathrm{dS} \cdot \mathrm{m}^{-1}$. For stolon number $\left(\mathrm{R}^{2}=0.96 ; \hat{\mathrm{Y}}=\right.$ $24.36-1.61 \mathrm{X})$, the calculated $E C_{i w} 50$ value was $7.7 \mathrm{dS} \cdot \mathrm{m}^{-1}$. Perhaps the most interesting result from this study was that irrigating with water that had an $E C_{i w}$ at or above 19.1 $\mathrm{dS} \cdot \mathrm{m}^{-1}$ (2:1 blend, 1:1 blend, and sea water) inhibited the emergence and elongation of stolons completely. Thus, irrigating with water with a high enough level of salinity changed the growth habit of the 'SeaDwarf', which could negatively affect important turf characteristics such as rate of spread hence recuperative capacity.

The effect salinity had on quality parameters may have been related to development of osmotic stress producing physiological drought, direct ion toxicity from constituent ions such as $\mathrm{B}$ or $\mathrm{Na}^{+}$, nutrient imbalances, soil physical/chemical problems related to $\mathrm{Na}^{+}$, or combinations of these (Beard, 1973; Harivandi et al., 1992). Dissolved salts in the soil solution reduces the uptake of water in turf (Beard, 1973; Butler et al., 1985; Carrow and Duncan, 1998; Carrow et al., 2001; Harivandi, 1984; McCarty et al., 2003; Turgeon, 2002; Youngner, 1985). The result of reduced water uptake in plants is an internal moisture stress that has been linked to deleterious or adaptive changes (Chaves et al., 2002) leading to a number of morphologic modifications such as decreased tillering, decreased leaf number, thinner leaves, and reduced shoot elongation (Beard, 1973; Turgeon, 2002). In this study, plant tissue moisture level was in fact reduced from $782 \mathrm{~g} \cdot \mathrm{kg}^{-1}$ to $709 \mathrm{~g} \cdot \mathrm{kg}^{-1}$ as the $E C_{i w}$ increased from $11.7 \mathrm{dS} \cdot \mathrm{m}^{-1}$ to $49.4 \mathrm{dS} \cdot \mathrm{m}^{-1}$. Whether this reduction in moisture constituted a physiological drought was unknown. The morphologic changes observed in this study might have been adaptive responses intended to help reduce the plant need for water, but this was not proven.

\section{Conclusion}

Irrigating 'SeaDwarf' with nonpotable water having higher levels of salinity had an observable effect on its quality, because the salinity induced changes in several important plant characteristics that collectively contribute to turf quality. These parameters changed presumably in response to osmotic stress associated with high levels of salinity. Irrigating with nonpotable water sources having a salinity level of $\geq 19.1 \mathrm{dS} \cdot \mathrm{m}^{-1}$, which was the $2: 1$ blend, seemed to produce the worst quality turf in terms of stolon growth and development and shoot growth. Irrigating with sources having salinity levels of $<19.1 \mathrm{dS} \cdot \mathrm{m}^{-1}$ produced better quality turf. Thus, from the results of this study, it appears that nonpotable water at a dilution of $3: 1$ or more can successfully be used for irrigating 'SeaDwarf'. Whether this would be true for field situations has yet to be demonstrated. Although 'SeaDwarf' exhibited moderately good salt tolerance in this study, irrigating it with water having lower levels of salinity resulted in better-quality turf. 


\section{Literature Cited}

Beard, J.B. 1973. Turfgrass: Science and culture. Prentice Hall, Englewood Cliffs, N.J.

Butler, J.D., P.E. Rieke, and D.D. Minner. 1985. Influence of water quality on turfgrasses, p. 7184. In V.A. Gibeault and S.T. Cockerham (eds.). Turfgrass water conservation. Univ. of California Coop. Ext. Publ. 21405.

Carrow, R.N. and R.R. Duncan. 1998. Salt-affected turfgrass sites: Assessment and management. Ann Arbor Press, Chelsea, Mich.

Carrow, R.N., D.V. Waddington, and P.E. Rieke. 2001. Turfgrass soil fertility and chemical problems. Ann Arbor Press, Chelsea, Mich.

Chaves, M.M., J.S. Pereira, J. Maroco, M.L. Rodrigues, C.P.P. Ricardo, M.L. Osorio, I. Carvalho, T. Faria, and C. Pinheiro. 2002. How plants cope with water stress in the field: Photosynthesis and growth. Ann. Bot. (Lond.) 89:907-916.

Dudeck, A.E. and C.H. Peacock. 1985. Effects of salinity on seashore paspalum turfgrasses. Agron. J. 77:47-50.

Duncan, R.R. 2001. All seashore paspalums are not created equal. Golf Course Management 69:54-60.

Duncan, R.R. and R.N. Carrow. 2000. Seashore paspalum: The environmental turfgrass. Ann Arbor Press, Chelsea, Mich.
Duncan, R.R. and R.N. Carrow. 2005. Managing seashore paspalum greens. Golf Course Management 73:114-118.

Environmental Turf. 2006. SeaDwarf seashore paspalum. http://www.environmentalturf.com/ grasses_seadwarf.html. Environmental Turf, Inc., Fort Pierce, Fla. Accessed 1 Sept. 2006.

Harivandi, M.A. 1984. Managing saline, sodic, or saline-sodic soils for turfgrasses. California Turfgrass Culture. 34:2-3.

Harivandi, M.A., J.D. Butler, and L. Wu. 1992. Salinity and turfgrass culture, p. 207-229. In D.V. Waddington, R.N. Carrow, and R.C. Shearman (eds.) Turfgrass. Agron. Mono. 32. ASA, CSSA, and SSSA, Madison, Wis.

Johnson, G.V. 1974. Simple procedure for the quantitative analysis of turfgrass color. Agron. J. 66:457-459.

Lee, G., R.N. Carrow, and R.R. Duncan. 2005. Criteria for assessing salinity tolerance of the halophytic turfgrass seashore paspalum. Crop Sci. 45:251-258.

Lee, G., R.R. Duncan, and R.N. Carrow. 2002. Initial selection of salt-tolerant seashore paspalum ecotypes. USGA Turfgrass and Environmental Research Online 1:1-7.

McCarty, L.B., I.R. Rodriguez, B.T. Bunnell, and F.C. Waltz. 2003. Fundamentals of turfgrass and agricultural chemistry. John Wiley and Sons, Hoboken, N.J.
Richards, L.A. (ed.). 1954. Diagnosis and Improvement of Saline and Alkali Soils. U.S.D.A. Handb.60. U.S. Gov. Print. Office, Washington, D.C.

Saltscape Solutions. 2006. Seashore paspalum turf grass for salt water irrigated golf courses. http://www.paspalumgrass.com/varities. asp. SaltScape Solutions, LLC, Bokeelia, Fla. Accessed 18 Aug. 2006.

Steel, R.G.D. and J.H. Torrie. 1980. Principles and procedures of statistics: A biometrical approach. McGraw-Hill Book Co., N.Y.

Turgeon, A.J. 2002. Turfgrass management. Prentice Hall, Upper Saddle River, N.J.

Undersander, D., D.R. Mertens, and N. Thiex. 2003. Forage analysis procedures. http:// www.foragetesting.org/index.php?page $=\mathrm{lab}_{-}$ procedures. National Forage Testing Association, Omaha, Neb. Accessed 15 July 2005.

Youngner, V.B. 1985. Physiology of water use and water stress, p. 39-43. In V.A. Gibeault and S.T. Cockerham (eds.). Turfgrass water conservation. Univ. of California Coop. Ext. Publ. 21405.

Zinn, S. 2004a. Suggestions for the care of seashore paspalum. Environmental Turf, Inc., Fort Pierce, Fla.

Zinn, S. 2004b. Deep roots, dwarf habit, salinity tolerance: 'SeaDwarf' paspalum looks promising. Florida Turf Digest. March/April:24-25. 